

\section{LEGAL NOTICE}

This report was prepared as an account of Government sponsored work. Neither the United States, nor the Commission, nor any person acting on behalf of the Commission:

A. Makes any warranty or representation, expressed or implied, with respect to the accuracy, completeness, or usefilness of the information contained in this report, or that the use of any information, apparatus, method, or process disclosed in this report may not infringe privately owned rights; or

B. Assumes any liabilities with respect to the use of, or for damages resulting from the use of any information, apparatus, method, or process disclosed in this report.

As used in the above, "person acting on behalf of the Commission" includes any employee or contractor of the Commission, or employee of such contractor, to the extent that such employee or contractor of the Commission, or employee of such contractor prepares, disseminates, or provides access to, any information pursuant to his employment or contract with the Commission, or his employment with such contractor.

Printed in USA. Price $\$ 2.00$

Avallable from the Clearinghouse for Federal Scientific

and Technical Information, National Bureau of Standards,

U. S. Department of Commerce, Springfield, Virginia 
Reactor Technology (TID-4500, 45th Ed.)

\title{
LEAK TESTING OF THE HWCTR CONTAINMENT BUILDING
}

\author{
by
}

S. H. Kale

T. C. Gorrell

E. 0 . Kiger

L. M. Arnett

Approved by

L. M. Arnett, Supervisor HWCTR Task Force

October 1965

E. I. DU PONT DE NEMOURS \& COMPANY

SAVANNAH RIVER LABORATORY

AIKEN, SOUTH CAROLINA

CONTRACT AT(07.2).1 WITH THE

UNITED STATES ATOMIC ENERGY COMMISSION 


\begin{abstract}
Special techniques were developed to measure the total leak rate from the containment building and to determine the location of small leaks. The contalnment structure was a composite steel and prestressed reinforced concrete bullding. The series of tests conducted showed that the leak tightness of the bullding inftially decreased with time. The periodic tests that are described permitted leaks to be found and repaired, so that the leakage was maintained at an acceptably low value.
\end{abstract}




\section{CONTENTS}

$\underline{\text { Page }}$

List of Tables iv

List of Figures iv

Introduction I

Summary 1

Discussion 2

Design Objectives 2

Description of Containment Building 2

Requirements of Low-Leakage Construction 5

Seals for Contalnment Bullding Penetrations 5

Construction Features and Techniques 9

First Test Series 9

Completion of Construction 11

Second Test Serles 12

Test Results 12

Investigation and Repair Techniques 12

Leakage Through the Concrete 14

Third Test Series 15

Additional Leakage Reduction Efforts 17

Fourth Test Series 18

Fifth Test Series 24

Leak Rate Test Procedures $\quad 24$

Preparation for Test 25

Test Procedure 25

Calculation of Leak Rate 29

Evaluation of Containment Bullding 32

Bibllography 33

Append1x - Conversion of 5 psig Leak Rate to 24 psig Leak Rate 34 


\section{LIST OF TABLES}

Table

$\underline{\text { Page }}$

I Contalnment Bullding Leak Test Results

II Leakage Sites Detected During Tests

III Leak Rates During 1963 Test

\section{LIST OF FIGURES}

F1gure

I Containment Building 3

2 Group I P1pe Seal (Below Grade) 6

3 Electrical Conduit Seal 7

4 Instrument Tubing Junction Box 8

5 Main Jolnt of Reactor Building 10

6 Section of Instrument Iine Conduit 19

$7 \quad$ Section of Instmument Iine Condult 20

8 Section of Instrument Iine Conduit 2 I

9 Section of Instrument Line Conduit 22

10 Section of Instrument Line Conduit 23

11 Test Arrangement 26

12 Change in Manometer $\Delta \mathrm{P}$ During Test 4

13 Change in Bullding Parameters During Test 4 


\section{LEAK TESTING OF THE HWCTR CONTAINMENT BUILDING}

\section{INTRODUCTION}

The Heavy Water Components Test Reactor (HWCTR) was designed and constructed to test fuel assemblies and other reactor components at power ratings and exposures expected in full-scale power reactors. The HWCTR is a pressure vessel reactor, moderated and cooled with $\mathrm{D}_{2} \mathrm{O}$. The maximum power is about $70 \mathrm{MW}$. The design pressure and temperature of the reactor vessel are $1500 \mathrm{psig}$ and $315^{\circ} \mathrm{C}$.

Containment for the HWCTR is provided by a composite steel and concrete bullding. Th1s was selected as the most economical type of building to meet the requirements of the HWCTR. The portion below grade consists of prestressed concrete walls on a flat concrete base with the base joint and walls sealed by plastic fllm coating. The bullding above grade is a welded steel cylindrical shell and hemispherical dome. The buliding was designed for a leak rate of $1 \%$ of the contents per day at an internal pressure of $24 \mathrm{ps} 1 \mathrm{~g}$. Design and construction features of the buliding are given in reference 4.

A large number of tests have been conducted to measure the leak rate of the containment building and to determine the sites of the leakage. This report describes the low-leakage design features of the containment building, the leak sites that have been found, and the methods for detecting leaks and for measuring the total building leak rate.

\section{SUMMARY}

A leakage rate of $0.6 \%$ per day at $24 \mathrm{psig}$ was found w1th the basic she1l, before installation of plping and conduits. Later results with the completed faclilty were higher, sometimes as high as $8 \%$ per day at $24 \mathrm{psig}$, prior to corrective measures. However, the results of tests and analyses indlcated that leakage rates as low as 2 to $3 \%$ of bullding volume per day at $24 \mathrm{psig}$ were achieved without extensive modifications. To maintain this leak rate, periodic tests were conducted to locate and repalr leak sites. A hazards evaluation of the maximum credible accident showed that the leak rate is required to be less than $7 \%$.

The series of tests conducted between November 1960, and August 1964, showed that seals and fittings were deteriorating. The major leak sites were at the 1ndividual condult seals and in the concrete floor slab at the foundation level. 


\section{DISCUSSION}

\section{DESIGN OBJECTIVES}

The use of concrete and steel as structural material for containment buildings is discussed in Reference 1. All-steel bulldings require a substantial amount of concrete below grade to protect the shell from active earth pressures and surcharges. The curvature of the bottom steel shell requires speclal design considerations to provide adequate floor space at the foundation level.

The major design objective with the HWCTR was to provide a less costly structure that was adequately leaktight and with maximum usable space. A composite structure consisting of a steel shell above grade and prestressed concrete below grade was selected to meet these requirements. It was the first structure of 1 ts $\mathrm{klnd}$ to be used as a containment bullding.

To withstand the pressure bulldup from the maximum credible accldent, and to prevent the spread of the resultant radioactivity, the containment building was designed and constructed as a pressurecontaining vessel. The bullding was deslgned for an objective leak rate of less than $1 \%$ of the total free volume per 24 hours at a pressure of $24 \mathrm{psig}$ at $108^{\circ} \mathrm{C}$, which is equal to the maximum equilibrium pressure that could result from accidental rupture of the pressurized system when it is full of $\mathrm{D}_{2} \mathrm{O}$ at $285^{\circ} \mathrm{C}$. The mechanisms of the pressurization of the bullding and the consequences of the radioactivity leakage are discussed in the HWCTR hazards evaluation reports $(2,3)$. Insofar as possible, the contalnment bullding was designed and constructed in accordance with interpretations of the 1956 ASME Boller and Pressure Vessel Code, Section VIII, Unfired Pressure Vessels. The design of the exterior prestressed concrete wall was based on "Criterla for Prestressed Concrete Bridges," 1955 Bureau of Public Roads, and "Tentative Recommendations for Prestressed Concrete," ACI-ASCE Joint Committee 323.

\section{DESCRIPTION OF CONTAINMENT BUILDING}

The reactor and principal auxiliary equipment are housed in the contalnment building, which is shown in Figure 1.

The building is 70 feet in diameter and 122 feet, 6 inches in over-all height. The lowest floor surface 1 s 52 feet, 6 inches below grade. The total enclosed volume is 420,000 cublc feet and the free volume is 320,000 cublc feet. The bullding below grade is an 18 -inchthick prestressed cylindrical concrete wall on a flat 5-foot-thick concrete base; the building above grade is a welded steel shell with a hemispherical dome. 


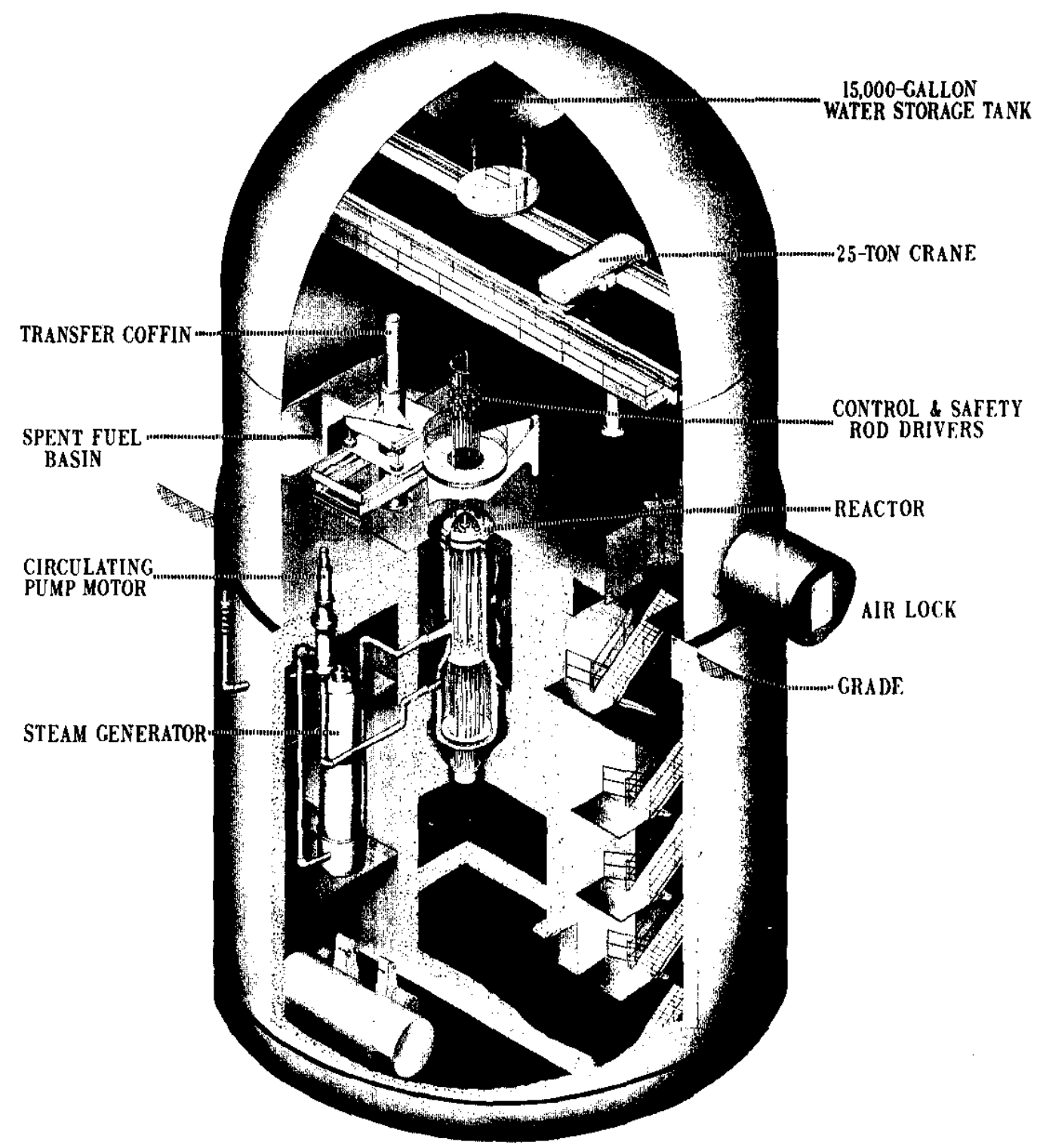

FIG. 1 CONTAINMENT BUILDING 
The building is designed for a differential of external pressure over internal pressure of $0.75 \mathrm{psi}$. A vacuum breaker is provided to prevent external pressure exceeding internal pressure more than 0.25 psi. No relief is provided for excessive internal pressure.

All compartments within the bullding are interconnected to facilitate equilization of pressures in event of localized rupture of the high pressure coolant systems. A 14- by 19-foot stairwell connects all levels of the building, and grating floors are used wherever compatible with structural and shielding requirements. The entire free volume of the building is accessible to gases or vapors released from the reactor system.

Personnel have access to the building via two air locks, one reserved for emergency use. The alr lock for normal access is a chamber 10 feet in diameter and 16 feet long that contains two doors, one leading outside and the other leading to the contalnment vessel. Both doors are sealed by mechanically loaded gaskets. The gaskets face the interior of the building, so they are further loaded by any excess pressure within the building. The two doors are equipped with interlocks that prevent opening one unless the other is closed. The emergency air lock is of the same design as the air lock for normal access, but is smaller.

To permit movement of equipment into and out of the bullaing, the structure contains an opening 7 feet wide and 7 feet high. During reactor operation, this opening is sealed by a steel door gasketed and bolted to the shell of the bullding. The seal is at the inside surface of the shell so any internal pressure developed in the bullding assists in maintalning the load on the seal.

Pressure-tight seals are provided where the bullding is penetrated by service piping and conduit. The largest penetrations are for two alr ducts of 24 -inch diameter, one for fresh air, the other for exhaust air. These ducts are welded to the bullding shell. Each duct contains 2 alroperated butterfly valves in serles that close in approximately 0.8 second on signal from the control bullaing. Service lines through which any building pressure could be relieved contain isolation valves that are operated when an "1solation" signal is recelved from the control bullding. Electrical condults are routed into the bullding via the concrete substructure and terminate in junction boxes inside the building. 


\section{REQUIREMENTS OF LOW LEAKAGE CONSTRUCTION}

To provide a building with a low leakage rate, it is necessary to provide many special seals and unusual features not found on conventional bulldings. In addition, special care in the construction must be exercised.

\section{Seals for Containment Building Penetrations}

Penetration of the containment building is necessary to admit services and personnel to the process equipmént. There are four functional groups of penetrations, as follows.

- Group I: Penetrations for pressurized sealed systems, such as secondary cooling water and steam discharge. There are 24 of these penetrations. The piping that goes through the concrete below grade has the type of seal shown in Figure 2. Plping passing through the steel shell is welded directly to a sleeve that is welded to the shell.

- Group II: Penetrations for services that are not pressurized, such as electrical and instrument conduits, and a transfer opening in the spent fuel basin. Each electrical conduit has the type of seal shown in Figure 3. There are 222 of these penetrations. All instrument air impulse Iines penetrate the contalnment shell through the junction box shown in Figure 4. There are 133 individual bulkhead connections to the function box, including spares.

- Group III: Penetrations for service such as ventilating and vent systems that could discharge activity to the environment if activity were released within the building. There are elght penetrations in this group. They include a bullding vacuum breaker, Iow pressure system seal pot vent, sump pump discharge line, 24-inch ventilation supply and exhaust ducts, sample sink vent, reactor gas vent line, and reactor safety valve discharge line. The safety valve discharge line and ventilation lines have a1r-operated butterfly-type valves that can be operated to provide 1solation. The others have air-operated isolation valves or are normally closed during operation.

- Group IV: The main personnel access air lock, an emergency personnel unlock, and a bolted equipment access door. These entry points are closed during periods of reactor operation or fuel discharge. 


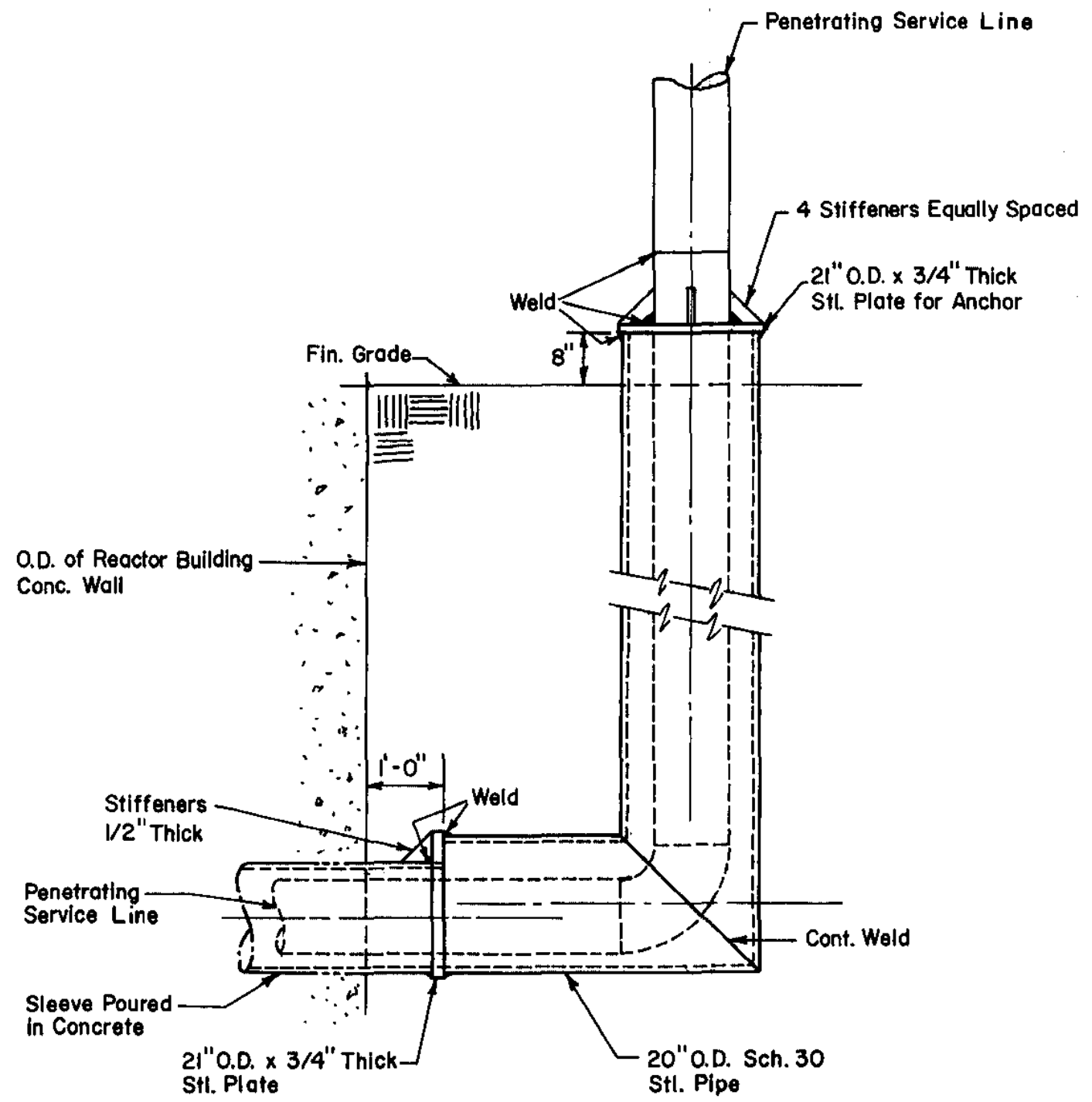

FIG. 2 GROUP I PIPE SEAL (BELOW GRADE) 


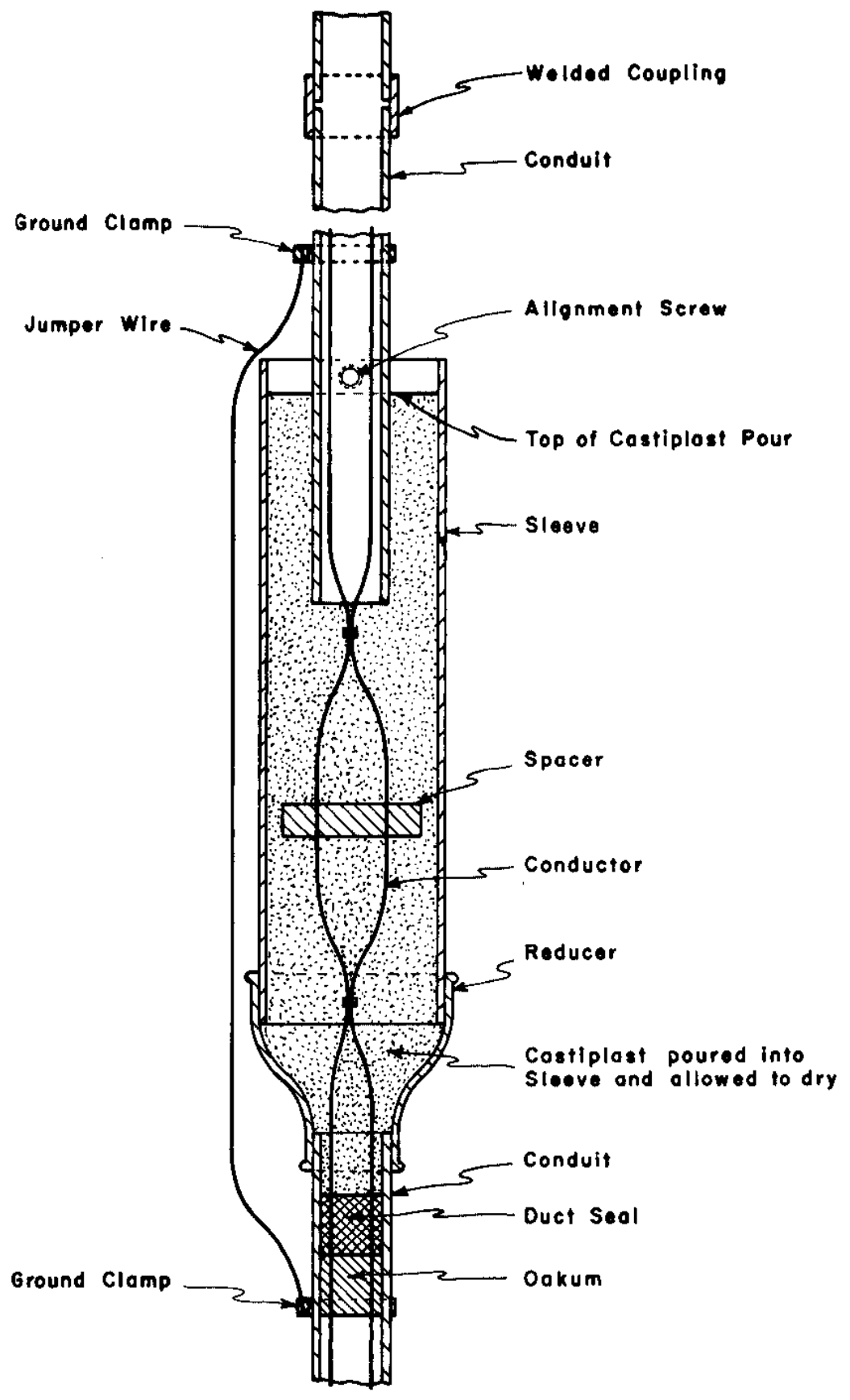

FIG. 3 ELECTRICAL CONDUIT SEAL 


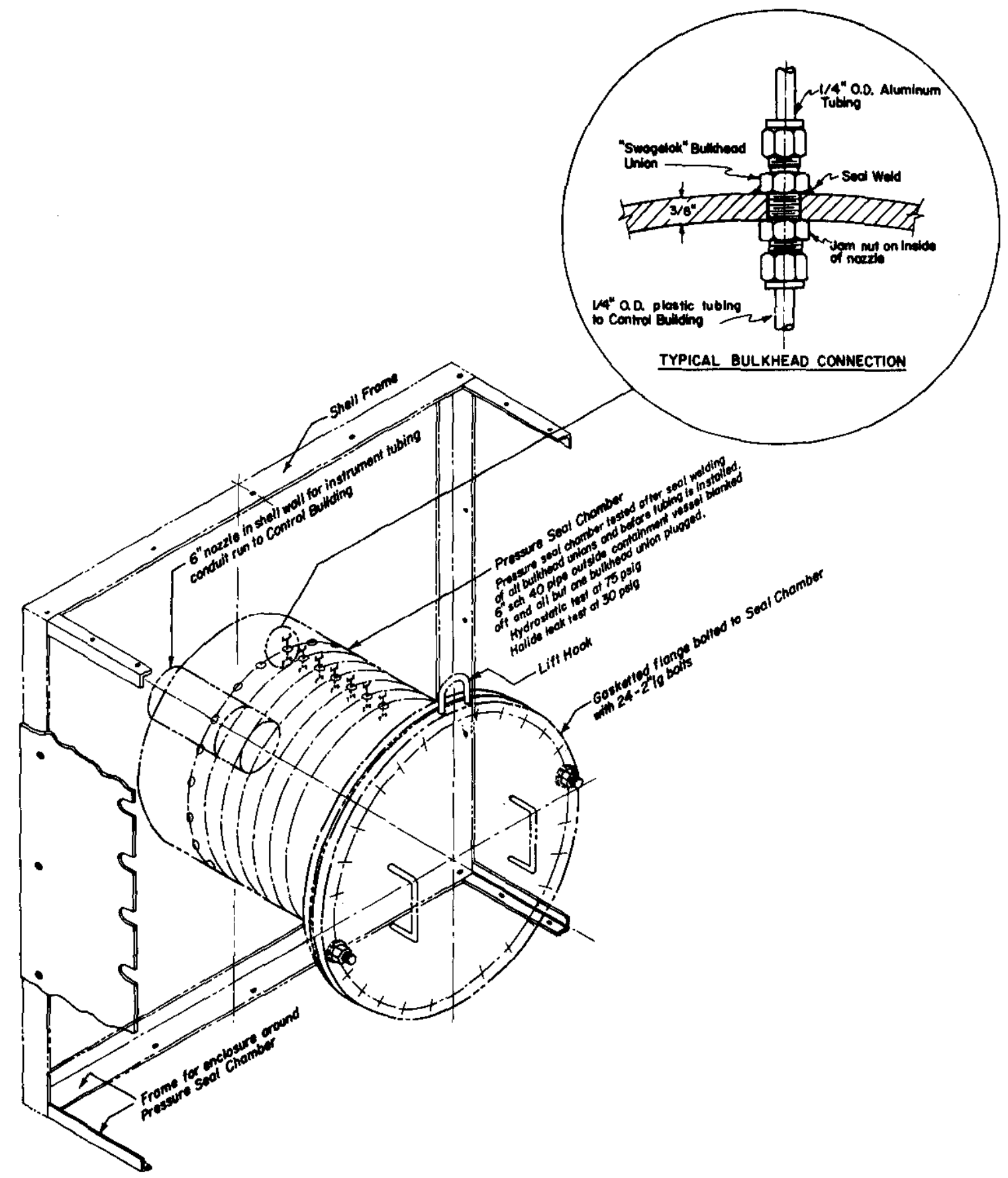

FIG. 4 INSTRUMENT TUBING JUNCTION $80 \mathrm{X}$ 
The experience with maintaining leaktightness of these penetrations during pressure testing is described in later sections.

\section{Construction Features and Techniques}

In addition to sealing the penetrations through the building, four other construction features were incorporated to reduce leakage.

1. The concrete walls below grade were poured as a single unit or structure. Although monolithic pours are unusual for walls of this thickness, helght and volume (approximately 625 cublc yards) built with conventional forms, it was hoped to obtain a wall free from cracks or jolnts. A number of cracks did develop, however.

2. After the walls and floors were poured, 39 steel bands were placed around the concrete walls and stressed to 155,000 pounds. The bands strengthened the concrete shell, and prevented cracks from opening further. The tension on the bands was sufficient to place the concrete in compression at internal pressures of up to $125 \%$ design pressure. The required wall thickness was reduced by about 3 feet, as compared with a conventional wall, resulting in a substantial economic advantage.

3. To reduce the concrete wall permeability, the interior walls were painted with a thermal sett1ng, nonporous plastic resin ("L1quid TIle"*) over "Flberglas"** cloth. Joints at floors and steel plates have a small overlap.

4. A sealed folnt was constructed at the 0-foot-level slab and is shown in Figure 5. Only the seal deslgnated as "water stop" was installed around the slab at the minus 52 foot, 6 inch level. The amount of leakage from these locations is discussed in later sections.

Further details are given in Reference 4.

\section{FIRST TEST SERIES}

To determine that the design and construction were adequate, a structural proof test at $29 \mathrm{psig}$ and a leakage test at $24 \mathrm{ps} 1 \mathrm{~g}$ were conducted in October and November 1960, after completion of the basic contalnment shell, but before any thermal insulation or any equipment was installed.

* "Llquid T1le" is a product of Evershield Products, Inc.

* "Fiberglas" is a product of the Owens-Corning Fiberglas Corp. 


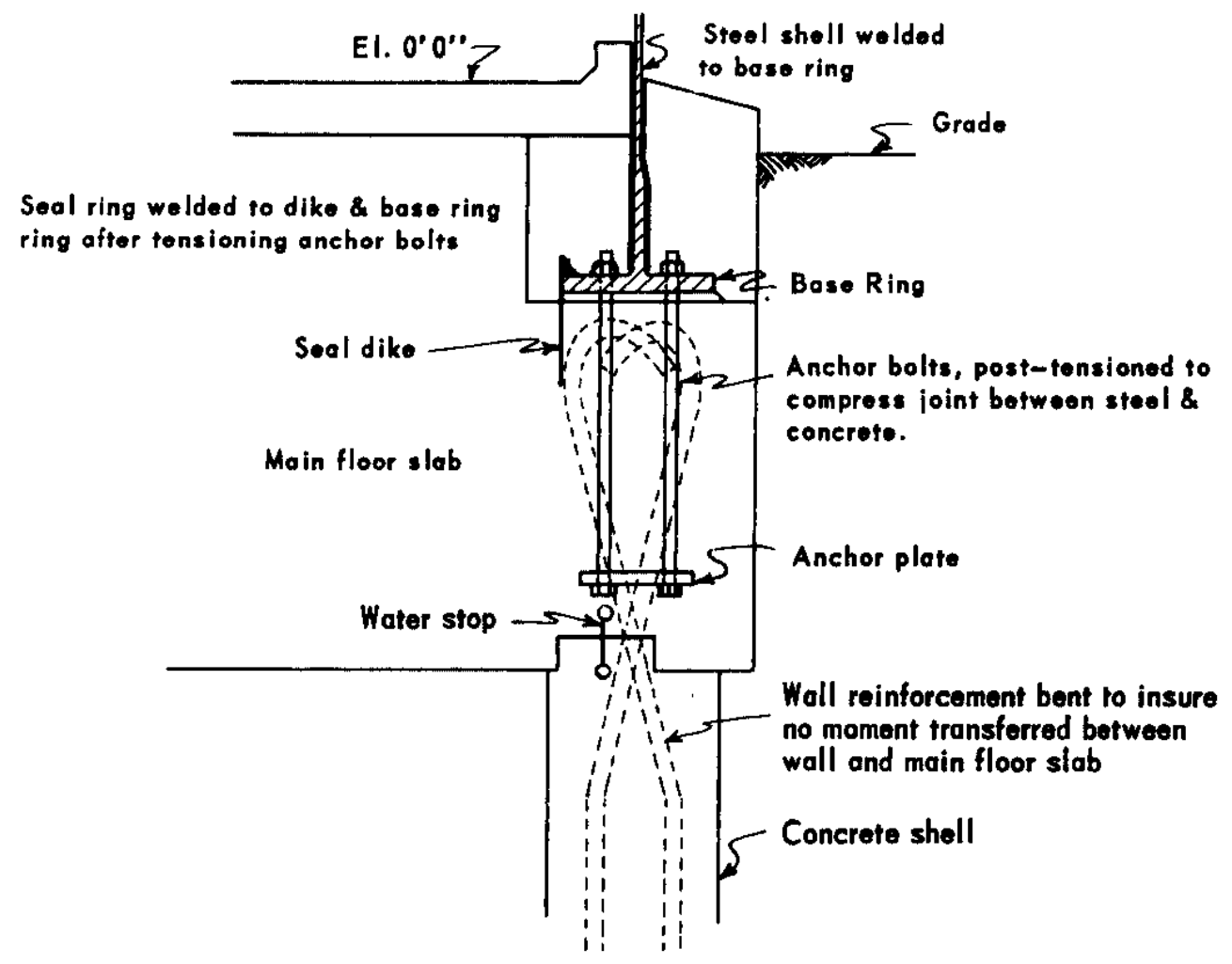

FIG. 5 MAIN JOINT OF REACTOR BUILDING 
To avold combining thermal and pressure stresses at the shellconcrete slab intersection, the bottom five feet of the shell was shaded from the sun with tarpaulins. The pressure was then applied in 5 psi increments up to 15 psig with inspection after each increment. During this progression, the pressure was overmun by 1 psi and then reduced before the inspection, for reasons of safety. Between $15 \mathrm{psig}$ and $29 \mathrm{psig}$, the increment was reduced to $2.5 \mathrm{psi}$. Waiting periods between increments allowed adjustment of stresses and strains. The pressure of $29 \mathrm{psig}$ was held for 15 minutes and then slowly bled down. Test observations were made from a concrete bunker, located 500 feet from the building.

The structural integrity of the building was demonstrated by the 29-psig test. Leaks through and along the penetrating conduits were repaired before the leak rate test was attempted.

During the leak rate test in November 1960, the leakage was $0.56 \%$ of building contents per day at $24 \mathrm{psig}$. At this time the various condults and pipes that penetrated the shell were fitted with temporary seals because electrical cables had not been installed and piping systems were incomplete or did not exist. Some leakage was observed through the concrete in the region of the main joint between the steel and concrete portions of the containment building, but the leak rate of $0.56 \%$ was well within the value of $1 \%$ being used in safeguards analyses at that time, and it was belleved that the additional painting and sealing planned in the construction program would be beneficial. Additional leakage tests, however, were planned when installation of equipment and electrical and hydraulic systems were complete. These tests were to be conducted at $5 \mathrm{psig}$ rather than $24 \mathrm{psig}$ to protect instrument systems that would be installed in the reactor bullaing.

\section{COMPLETION OF CONSTRUCTION}

In the period of one year between the tests discussed above and the first of the series of leakage tests at $5 \mathrm{ps} 1 \mathrm{~g}$, the various equipment systems within the containment bullding were installed, and internal and external connections were made to the various penetrations. A panel approximately 28 feet square was cut from the steel containment shell to permit entry of the reactor vessel. The panel was later welded in place. The cables were pulled through electrical conduits; the conduits were sealed within the contalnment shell and individually pressure tested for leakage. The seals were installed for each penetration of the concrete shell below grade. The inside surface of the concrete wall was painted with "Liquid Tile", over a "Fiberglas" mat. Instrument tubing was connected to the junction box. 


\section{SECOND TEST SERIES}

Test Results

A leak rate test at 5 psig bullding pressure was started November 5, 1961. The purpose of the test, or test series as it subsequently became, was to determine the leak rate after completion of all construction. The measured leak rate was $8.4 \%$, a factor of $15 \mathrm{~h}$ igher than the rate previously determined. Leak rates for this, and all subsequent tests, are listed in Table $I$.

The Appendix gives a description of the method used to convert the leak rate data obtalned at $5 \mathrm{psig}$ to the equivalent leak rate at 24 psig. Unless otherwise stated, all leak rates in this report are based on the equivalent $24 \mathrm{psig}$ condition.

"Freon"* was injected into the containment building and a hallde detector was used to locate the leaks. Outleakage was detected at the ends of 86 electrical conduits in the control house and electrical equipment building. Leakage past the butterfly valves in the ventilation systems was detected. Attempts were made to repair the leaks but the next test showed that the leak rate was almost unchanged. The repairs to the ventilation system valves were successful, but some condults continued to leak. At this time it was belleved that the high leakage rate was the result of a number of small leaks through the conduits because no gross leaks had been found.

Investigation and Repair Techniques

A program was started to repair leaking conduits or to eliminate them as a source of leakage. This phase of the program, which continued until January 19, 1962, included eight additional pressure tests of the bullding, and was successful in reducing the leak rate to about $3 \%$ per day. The following repairs and investigations were made:

1. Because the resin seal at the containment bullding end of each condult had been subjected to independent pressure tests, it was believed that alr was leaking into the condults through couplings between the resin seal and the point of entry into the concrete. Seal welding of these couplings and of the caps on spare condults proved to be inadequate and was abandoned in favor of sealing with "Fiberglas" and "Liquid Tile".

* "Freon" is a product of E. I. du Pont de Nemours \& Co., Inc. 
TABIE I

Containment Building Leak Test Results

\begin{tabular}{|c|c|c|c|c|c|c|c|}
\hline Series & $\begin{array}{l}\text { Test } \\
\text { No. } \\
\end{array}$ & Date & $\begin{array}{c}\text { Test } \\
\text { Pressure, } \\
\text { psig } \\
\end{array}$ & $\begin{array}{l}\text { Leak Rate, } \\
\text { At } 5 \text { psig }\end{array}$ & $\frac{\% \text { per day }}{\text { At } 24 \text { psig }}$ & $\begin{array}{c}\text { Test } \\
\text { Duration, } \\
\text { hours } \\
\end{array}$ & $\begin{array}{c}\text { Condition } \\
\text { of } \\
-52^{\prime} \text { Floor }\end{array}$ \\
\hline 1 & 1 & $11-19-60$ & 24 & 0.15 & 0.56 & 34 & Dry \\
\hline \multirow{12}{*}{2} & 2 & $11-5-61$ & 5 & 2.2 & 8.4 & 18 & Dry \\
\hline & 3 & $12-26-61$ & 5 & 2.2 & 8.5 & 6 & Dry \\
\hline & 4 & $12-28-61$ & 5 & 2.0 & 7.6 & 24 & Dry \\
\hline & 5 & $1-9-62$ & 5 & 1.8 & 6.8 & 5 & Dry \\
\hline & 6 & $1-12-62$ & 5 & 0.8 & 3.1 & 20 & Dry \\
\hline & 7 & $1-13-62$ & 12 & 0.8 & 3.3 & 13 & Dry \\
\hline & 8 & $1-14-62$ & 5 & 0.8 & 3.0 & 13 & Dry \\
\hline & 9 & $1-18-62$ & 5 & 0.8 & 3.1 & 16 & Dry \\
\hline & 10 & $1-19-62$ & 5 & 0.8 & 3.2 & 16 & Dry \\
\hline & 11 & $1-24-62$ & 5 & 0.7 & 2.5 & 6 & Dry \\
\hline & 12 & $1-25-62$ & 5 & 0.6 & 2.2 & 12 & Dry \\
\hline & 13 & $1-26-62$ & 5 & 0.2 & 0.7 & 8 & Flooded \\
\hline \multirow{4}{*}{3} & 14 & $9-24-62$ & 5 & 2.1 & 8.1 & $5 \frac{1}{2}$ & Dry \\
\hline & 15 & $9-25-62$ & 5 & 1.2 & 4.7 & 7 & Flooded \\
\hline & 16 & $9-29-62$ & 5 & 1.1 & 4.2 & $8 \frac{1}{2}$ & Wet \\
\hline & 17 & $9-30-62$ & 5 & 1.1 & 4.1 & 14 & Flooded \\
\hline 4 & 18 & $5-6-63$ & 5 & 0.76 & 2.87 & 58 & Dry \\
\hline 5 & 19 & $8-15-64$ & 5 & 0.65 & 2.5 & 18 & Dry \\
\hline
\end{tabular}

2. The method of detecting condult leakage with a "Freon" detector had IImitations because the conduits became saturated with "Freon" and the high background made further detection impossible. The method then adopted for condult leak detection was to place "Dux Seal"* at the external end of the conduit and then to spray the "Dux Seal" w1th soap solution and observe for bubbles. A successful variation of this method was to insert a tube into the "Dux Seal" and seal a plastlc bag on the other end of the tube. Inflation of the bag indicated leakage.

* "Dux Seal" is a product of the Johns-Manville Corporation. 
3. Because repairing the leaking condults was time consuming, 5 psig backpressure was applied to the external end of the conduits to stop outleakage. The effect on the over-all leak rate of eliminating one or more condults as leak sites gave a quantitative estimate of the leak rate through those particular conduits. A concentrated repair effort could them be applied to the worst leaklng conduits. However, when the bullding was not pressurized, this method could not be used to detect leaking condults because many of the conduits had leaks through couplings in the underground span between the external end and the containment bullding. Leakage through these couplings could not be differentiated from leakage into the containment building.

4. The main instrument function box forms the seal for all instrument air signal ilnes that run from the contalnment buliding to the control house. Each line was traced and air tested to be sure that the ends were not open.

5. All access doors were tested with soap solution periodically during each test. The doors were sealing adequately.

6. Many discharge paths from the building were blanked off and soap tested to insure tightness during the test. These included the building sump pump discharge line, hellum gas vent lines to the stack, the $D_{2}$ supply line, and a 12-inch, three-way valve that relieved reactor overpressure to the atmosphere or building. The building vacuum breaker was encased in a plastic bag.

7. Several systems were pressurized to greater than $5 \mathrm{psig}$ to prevent outleakage. These included the helium system, the heating and ventilating circulating water piping, and steam generator-miscellaneous heat exchanger cooling water systems. The spent fuel storage basin was filled to provide a water seal against air leakage.

8. All underground pipe seals penetrating the bullding through the sleeves shown in Figure 2 were individually tested and found to be t1ght.

The leak sites found during these and other tests are summarized in Table II.

\section{Leakage through the Concrete}

In January 1962, the leak rate persisted at 3.0-3.2\% despite repeated efforts to locate and eliminate leaks. Condults had been eliminated as a source of leakage by repalr or backpressure. The other penetrations had been eliminated. Four additional leaks were detected by observers in the containment building who listened for audible leaks 
whlle all fans and equipment were shut down. The leak sites found were a telephone cable conduit, a tiny hole in the concrete, a $1 / 4$ " gas line fitting, and an electrical condult. Repair of these leaks reduced the leakage rate to $2.5 \%$ (test number 11 , Table I).

It was then concluded that the leakage must be escaping underground through defects in the structure. The main joint between the steel shell, the concrete shell, and the zero level floor slab was one region suspected of leakage, and the joint between the basement floor slab and sumps was another.

The two-phase program developed to determine if either of the two regions was a major source of leakage was as follows: (1) excavate around the outside of the bullding to expose the main joint for soapbubble testing, and (2) flood the basement floor and sumps to provide a water seal. Soap tests of the main joint revealed that leakage was issuing from this region. Observers who observed the leakage from this region during the initial pressure test in November 1960, however, estimated that the leakage did not appear to be significantly larger.

With the basement flooded with seven inches of water, the leak rate was $0.66 \%$. The humidity increase resulting from evaporation from the large free surface of water caused a small pressure increase that was accounted for in the leak rate calculation. A good knowledge of the average humidity was obtained and the humidity changes were small. The maximum leak rate during the test period with no humidity correction applied was $0.85 \%$. It was concluded that the basement floor slab was a major contribution to the leak rate of $2.5 \%$. Additional leak testing was postponed until after the completion of the initial critical and low-power test period.

\section{THIRD TEST SERIES}

Leak tests were conducted in September 1962, to determine the leak rate prior to operating the HWCTR at appreciable powers. Test 14 (Table I) showed that the leak rate had increased to $8.1 \%$ since the January tests. Test 15 was then conducted with the basement floor flooded, and the leak rate was $4.7 \%$ per day. A number of leak sites were found, including electrical conduits, access doors, and 1solation valves. These leaks were repalred and tests 16 and 17 were made. The leak rate was $4.2 \%$ per day before the minus 52-foot-level floor was reflooded, and $4.1 \%$ per day after the floor was flooded. It is belleved that the cracks and voids in the floor slab had not dried out since test 15 and were still effectively sealed during test 16 . Minor leakage was detected at several condults, but no appreclable leakage was located. 
1. Electrical conduits - around the conduit through the concrete.

2. Main.shell jolnt.

3. Through electrical conduits.

a

4. Ventilation and relief double butterfiy valves.

5. Air lock and access doors.

6. Instrument tubing junction box connectionsuncapped spares and leaking connections.

7. Hole in concrete wall.

8. Gas line fitting.

9. $-52^{\prime}$ level floor slab at joint to wall.
Observation at walls and floor slab.

Observation of soap bubbles at exterior wall.

1. Listening to escaping air at the seal inside the building and at the exterior end.

2. "Freon" released in building and detected at exterior end with halide detector.

3. Detecting sound of leaking air with "Ultrasonic Translator"* inside bullding.

4. Sealing exterior end of conduit with "Dux Seal", inserting balloon and observing inflation.

5. Back-pressurizing conduits after sealing exterior end with "Dux Seal".

Audible leakage out drain valve between butterfly valves.

Observation of soap bubbles.

Individual pressure testing.

Audible to observer in pressurized bullaing.

Audible to observer in pressurized building.

1. Comparison of leak rates with floor both flooded and dry.

2. Sensing of vibrations using techniques developed by Mine Safety Applicance Company.

* "Ultrasonic Translator" is an ultrasonic sound detector manufactured by the Selcon Corporation. 


\section{ADDITIONAL LEAKAGE REDUCTION EFFORTS}

It was apparent that the leaktightness of the contalnment bullding had deteriorated between January and September 1962. A program was developed that had three major objectives:

1. Reanalyze maximum credible accident (MCA).

2. Develop a program to find and repair all leaks, and to evaluate other leak detection instruments.

3. Develop a method of sealling concrete slabs, walls, and joints.

The results of the MCA analysis showed that, with the addition of an internal lodine absorber system, an acceptable leak rate would be $7.6 \%$ per day with water on the floor at the minus 52 foot, 6 inch level (reference 3 ).

Because the measured leak rate was in excess of the rate used in the hazards evaluation, a limit was placed on the reactor power and total allowable fuel exposure. These limits reduced to an acceptable level the potential release of activity from the containment building in the event of an accident.

During a short leak test on December 29, 1962, a thorough search was made for additional leaks. Three additional condult leaks were found. One of the leaks was measured and had a rate of $1 \mathrm{scfm}$ at 5 psig. This could have accounted for approximately $1 / 3$ of the best September leak rate (Test 17). A repalr program was planned for an extended reactor shutdown in April 1963, that included:

1. Sealing of the spent fuel basin liner.

2. Repair of leaking conduits noted in the December 1962, test, plus others to be tested during the shutdown.

3. Installation of humidity and building temperature indicators.

4. Surveying building during test with an "Ultrasonic Translator" and other instruments developed by the Institute of Gas Technology and the Mine Safety Appliance Company.

The installation of an lodine absorber system in the containment building was also planned for this shutdown.

The liner and curbing around the spent fuel basin was sealed with "Fiberglas" and "Llquid Tile" in April. A test of the space between 
the liner and the concrete walls revealed no leakage at a pressure of $2^{\prime \prime} \mathrm{H}_{2} \mathrm{O}$. Four leaking condults were repalred. Two conduits were repaired by cutting out and replacing the old seals. Repairs to the conduit that leaked at 1 scfm were made with "Liquid Tile" and "Fiberglas". The fourth condult was repaired by tightening the threaded jolnts. Photographs of the seals that were removed are shown in Figures 6 through 9. Cracks extending through the resin as well as volds can be seen. In Figure 8, shrinkage from the end plate is also apparent.

\section{FOURTH TEST SERIES}

The fourth test series was conducted from May 3 to 6, 1963. A search for leak sites was made as the bullding was belng pressurized. Very small leaks were found at the bypass line to the stack exhaust Iine, the seven foot access door, the inner main air lock door, and the butterfly valves in the ventilation supply and building relief lines. Only the leak at the stack bypass line was repalred at this time. "Freon" was found leaking at 46 conduits. All of the conduit leaks were very small except for one that could be heard blowing.

Although the one conduit leak appeared to be sizable, it was not repaired at this time. Because the total leak rate was satisfactory, a delay in starting up the reactor to repair the seal was considered not justified. The conduit seal was cut out and replaced in September 1963. However, when the seal was tested after removal, the leak rate was only $1.6 \mathrm{scf} / \mathrm{hr}$ at $5 \mathrm{psig}$. This rate would have contributed only $0.01 \%$ per day to the leakage at 5 psig, or $0.038 \%$ per day at $24 \mathrm{psig}$.

This experience illustrates the difficulty of trying to determine the contribution of an individual leak to the total leak rate. No method has been found to measure the ind1vidual leaks in place, other than back pressurizing or repairing them, and then attempting to measure the difference in leak rate. This procedure is time consuming if 50 to 100 leaks are involved. Although a leak may appear small as it exhausts into the control house or electrical equipment building, it could be leaking at a high rate underground through condult couplings. The couplings connecting sections of condult together were not intended to be airtight, and it is possible that water leakage into them forms seals that make detection at the exterior ends impossible. As in the case of the particular seal, shown in Figure 10, a leak that appears large can actually be negligible in 1 ts contribution to the total. It should be noted that the resin is dense and there are no voids or cracks, as in the other seals. 


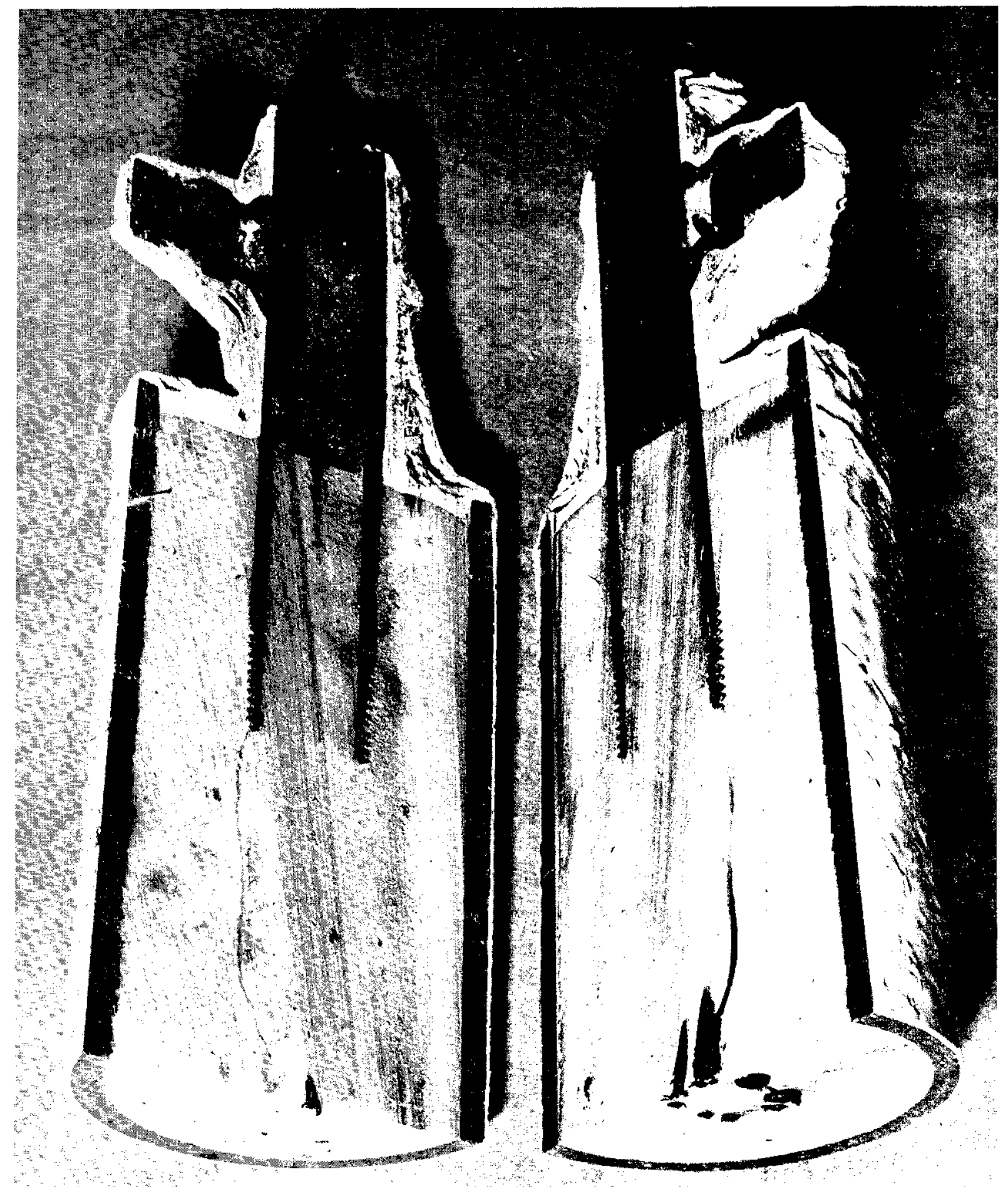

FIG, 6 SECTION OF INSTRUMENT LINE CONDUIT (NOTE CRACKS) 


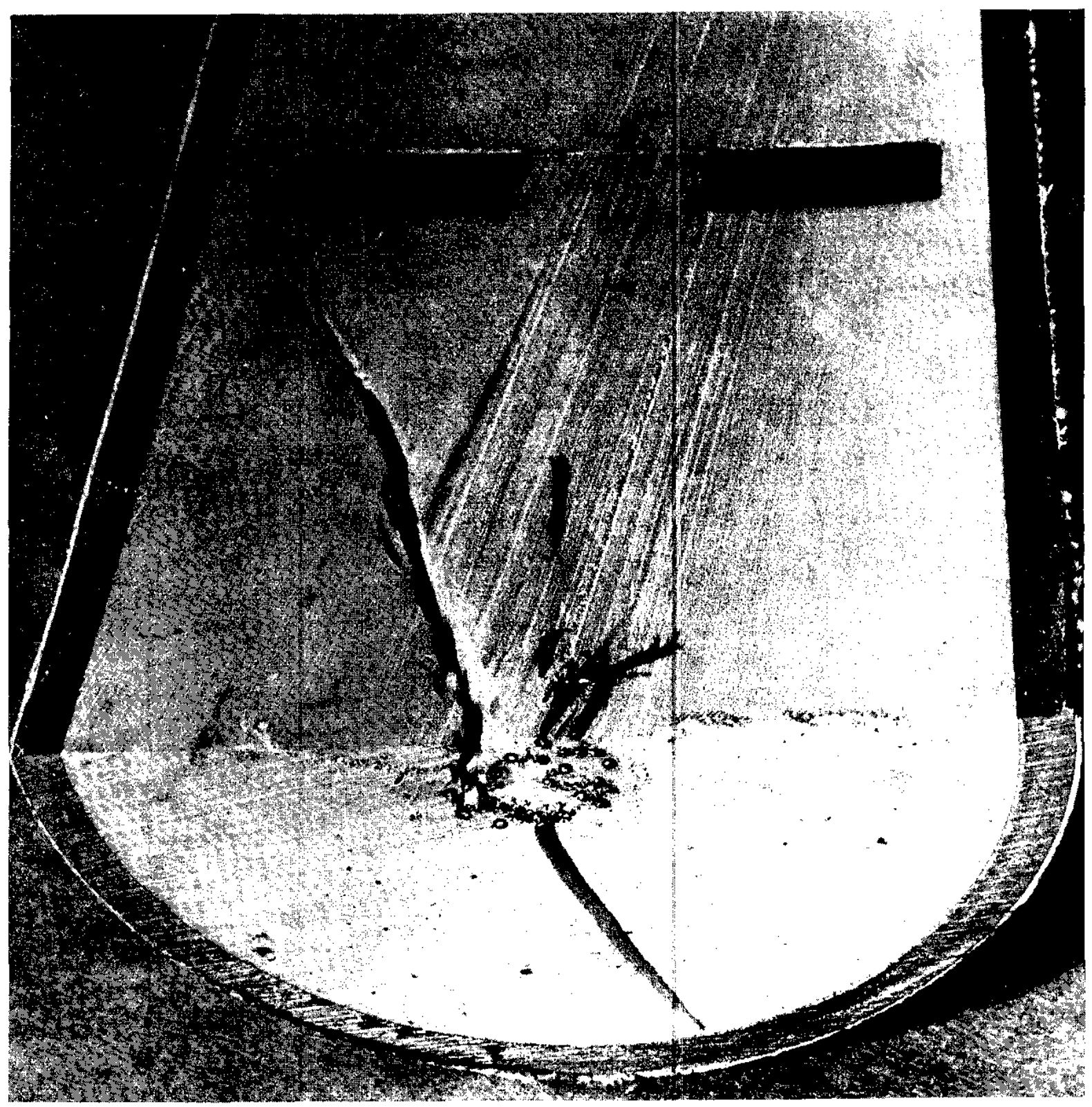

FIG. 7 SECTION OF INSTRUMENT LINE CONDUIT (NOTE VOIDS) 


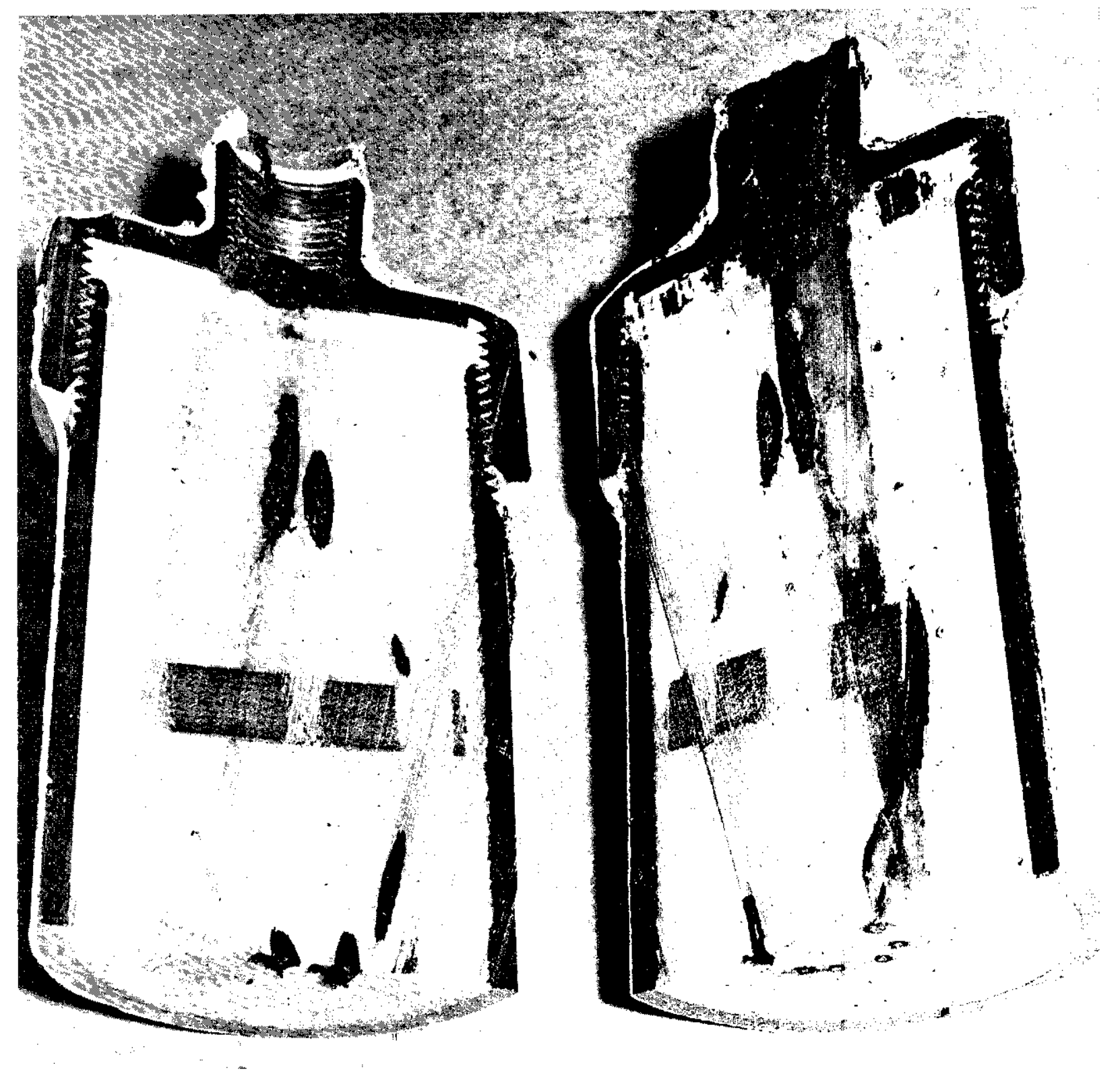

FIG. 8 SECTION OF INSTRUMENT LINE CONDUIT

(NOTE SHRINKAGE AWAY FROM SLEEVE SURFACE) 


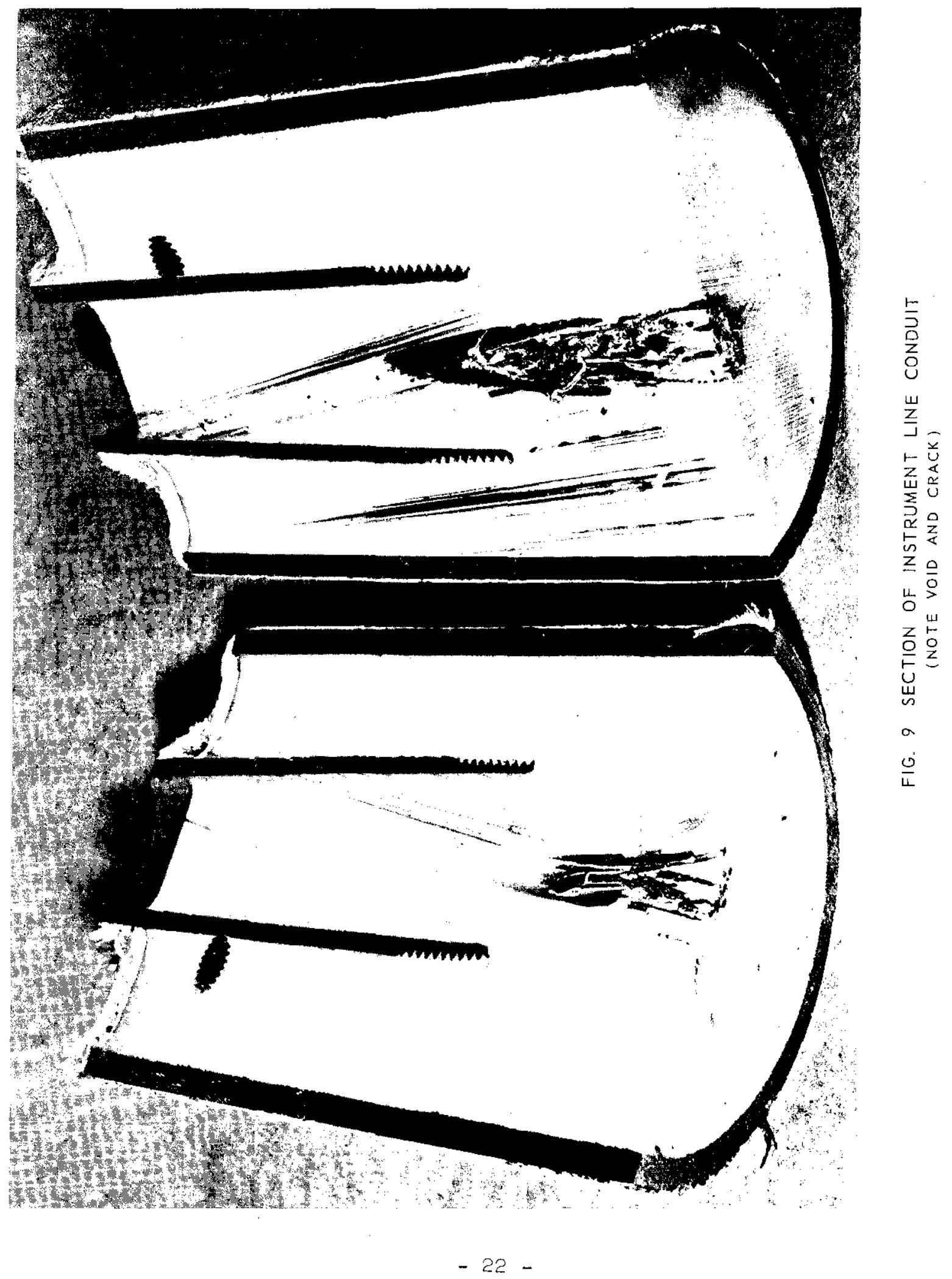




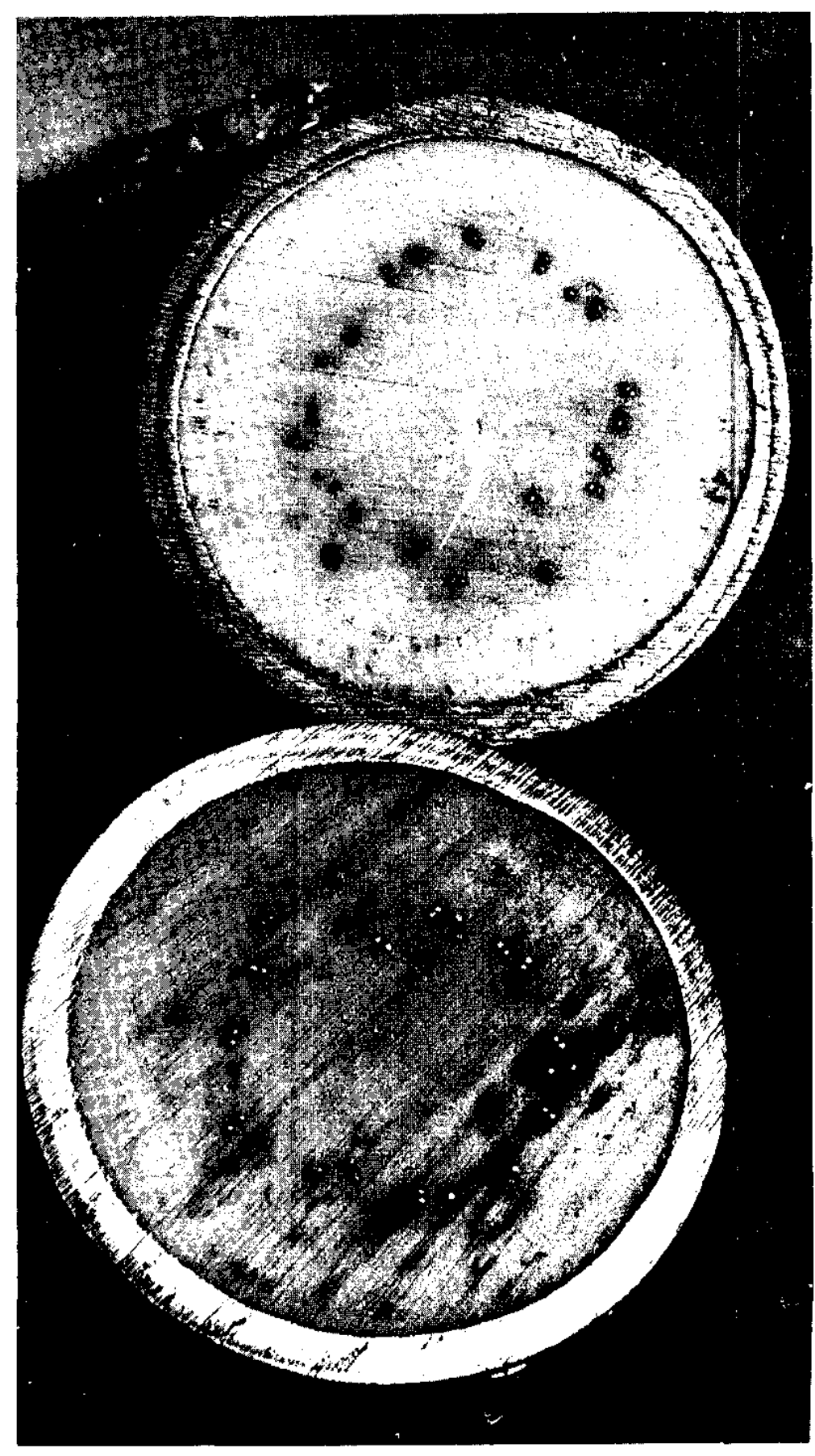

FIG. 10 SECTION OF INSTRUMENT LINE CONDUIT (SEAI L.EAKED AT RATE OF 1.6 SCFH AT 5 PSIG) 
Throughout the $2 \frac{1}{2}$ days of the test, conduits and other penetrations were examined for leakage. "Freon" had been released in the bullding and hallde leak detectors, together with the "UItrasonic Translator" were used to search for leaks outside the bullding. No containment bullding entries were made between 9 PM, May 3, and 10:30 AM, May 6 . The "Ultrasonic Translator" was not used inside the building.

On May 6, numerous entries were made to the building, primarily to allow a representative from Illinois Gas Institute to search for leaks. The test equipment consisted of a tripod base and magnetic base which were connected to a plezoelectric accelerometer. The output of the plezoelectric transducer was fed into a filter amplifier and monitored simultaneously on a decibel meter and earphones. The perimeters of the minus 52-foot-level slab, the zero-foot-level slab, and steel shell at zero level were investigated. It was concluded that four possible leak areas existed at -52 feet and three at zero level. The leaks appeared to be very small and widespread over the areas. No repairs were attempted.

The leak rate for the 58-hour perlod was $2.87 \%$ per day. Th1s rate is about $38 \%$ of the maximum allowed by the hazards evaluation (reference 3). The improvement over the September 1962, leak rate was attributed to the repairs made between September and May.

Installation of the lodine absorber untts was completed at this time, and the restrictions on reactor power and fuel exposure were removed.

\section{FIFTH TEST SERIES}

The fifth leak rate test was made on August 15 and 16, 1964. The measured rate was 2.5\% of building volume per day, with the basement floor dry. The procedures used were identical with those used in the fourth test.

A search for leak sites was conducted continuously during the test. One major leak was found in a butterfly valve, and was repaired.

\section{LEAK RATE TEST PROCEDURES}

The same general methods and procedures were used in all tests, although improvements were made in successive test series as the result of the experlence gained. The procedures used in the fourth and fifth test series provided a satisfactory method for measuring the leak rate. The detalls of the leak rate determinations are described below, with data from the fourth test included as an example. 
Preparation for Test

It Is necessary to shut off the air supply to instruments to prevent increasing the containment bullding pressure and giving erroneous leak rates. Because some tests are made while the reactor contains fuel and moderator, special precautions are required to ensure reactor safety, although the reactor is shutdown. Relatively simple changes are made in the process flows during the test so that only a few instruments are needed to assure safe reactor control. A temporary air compressor is installed inside the containment building to supply important pneumatic instruments. In the control room, blasing relays are Installed on these instrument recorders to permit periodic compensation for the changing bullding pressure.

As mentioned previously, numerous nonessential piping systems that penetrate the contalnment bullding are blanked. Pressure vessels and $\mathrm{D}_{2} \mathrm{O}$ storage drums are vented to prevent the posslblity of collapse. All nonessential machinery is shut down. The air conditioning units are left in operation to keep the internal air temperature as uniform as possible.

\section{Test Procedure}

The "reference tank" method of testing is used to minimize the effect of fluctuating ambient air temperature. The building is equipped with three reference tanks and the instrumentation shown in Figure 11 . With the jumper installed between the U-tube pressure taps, the reference tanks are opened to the bullaing. Alr is pumped into the building by a diesel-driven compressor. When bullding pressure reaches 5 psig, the compressor is shut down and disconnected from the pressurizing line. When the pressure in the reference tanks equalizes with the building pressure, as shown by the U-tube manometer, the valves are closed and the jumper is removed. Loss of bullding pressure is then measured by the change in the liquid level in the legs of the manometer. Air temperature in the thin-walled reference tanks follows the change in bullding temperature during the diurnal cycle. Although the $\Delta T$ is small, it is necessary to correct for 1 t.

An example of the $\Delta P$ data, for the fourth leak test, is shown in Figure 12. The building pressure and temperature and the reference tank temperature data are shown in F1gure 13. 


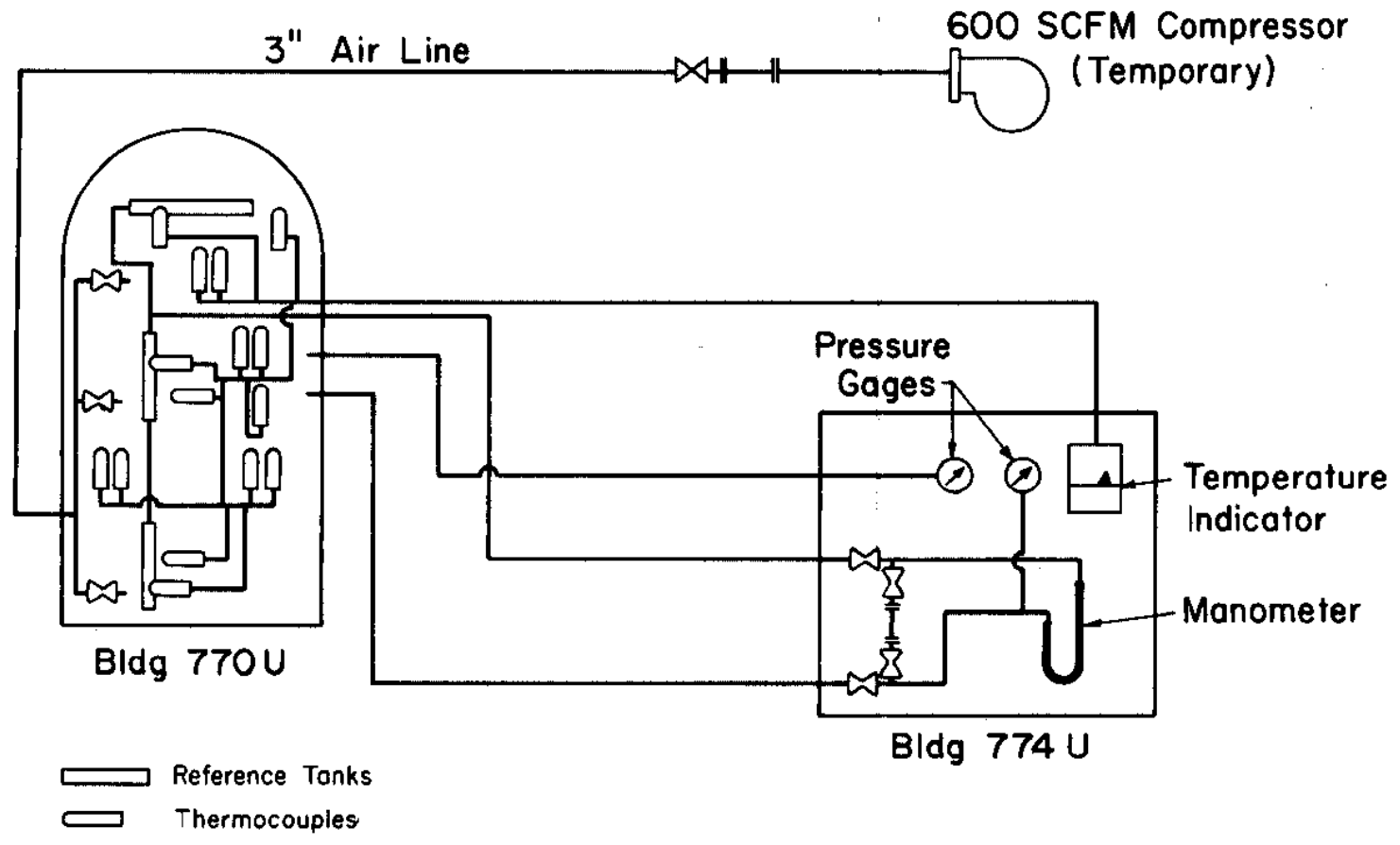

FIG。 11 TEST ARRANGEMENT 


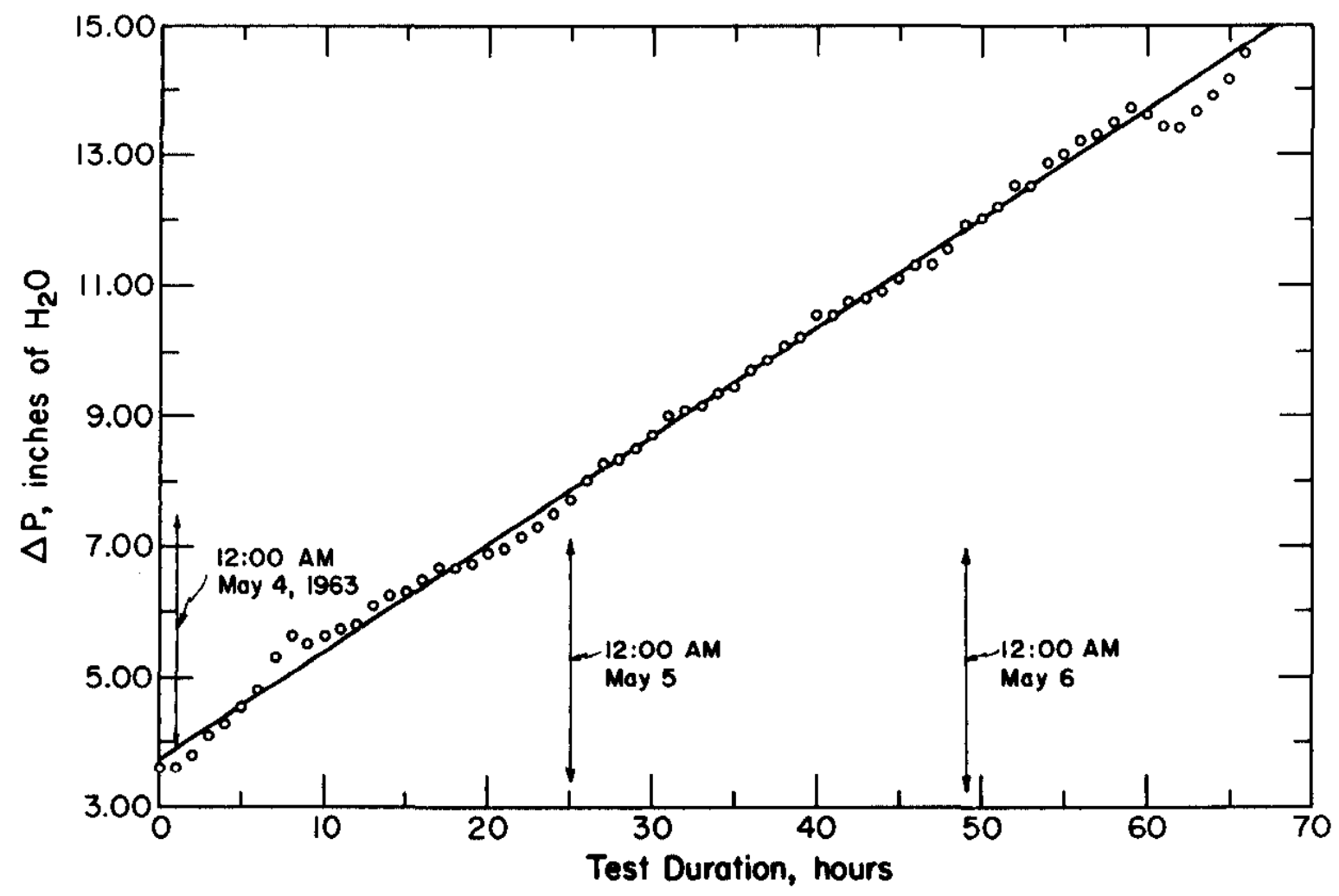

FIG. 12 CHANGE IN MANOMETER $\triangle P$ DURING TEST 4 

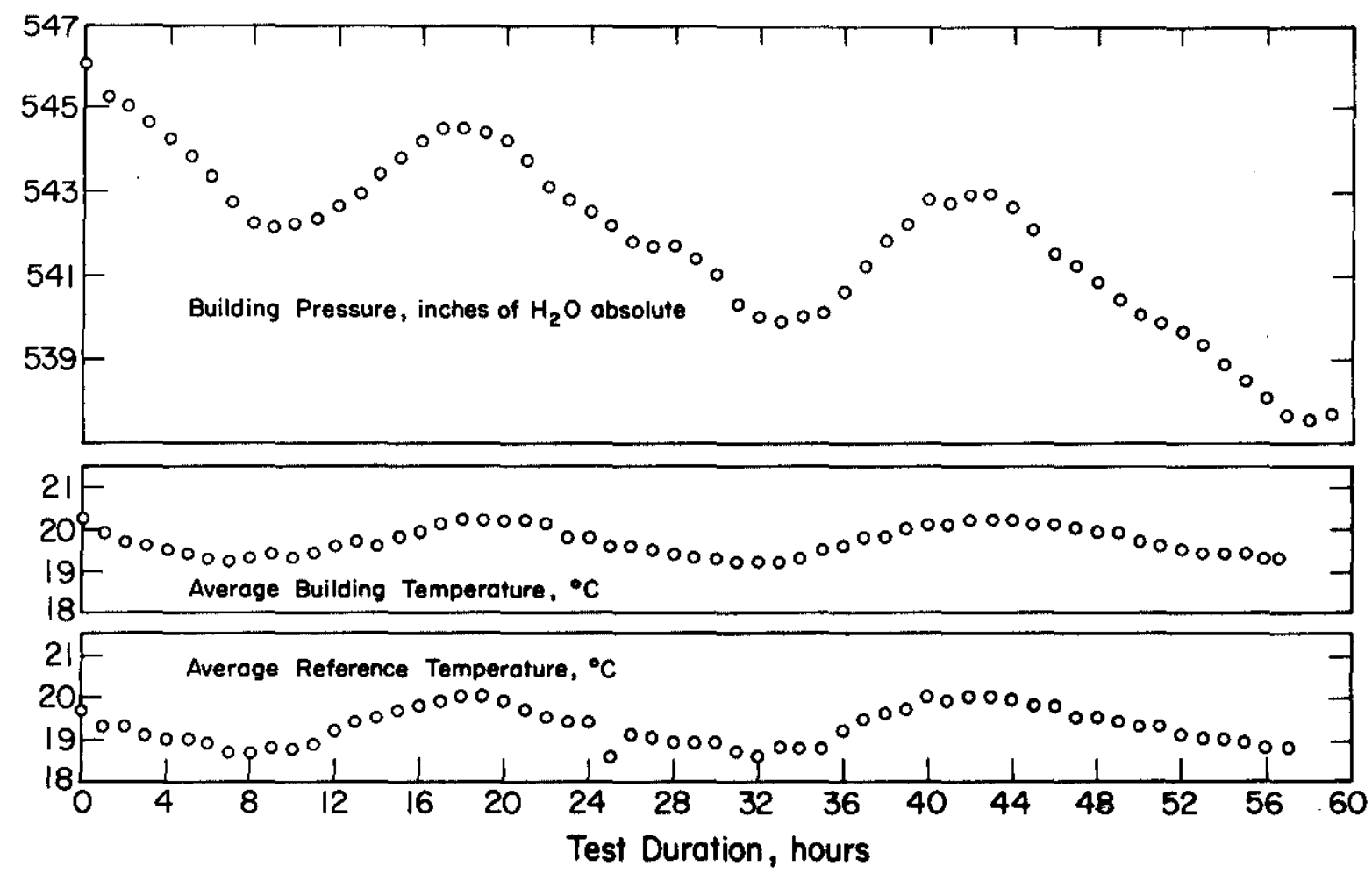

FIG. 13 CHANGES IN BUILDING PARAMETERS DURING TEST 4 
Calculation of Leak Rate

There are two ways in which the leak rate can be calculated. For the "reference tank" method, the leak rate is glven by:

$$
I=\left[\frac{\Delta \Delta P}{P_{r}}-\frac{\Delta \Delta T}{T_{b}}\right] \times \frac{24 \times 100}{t_{2}-t_{1}}
$$

and

$$
P_{r}=P_{b}+\Delta P
$$

where,

$$
\begin{aligned}
\mathrm{I}= & \text { leak rate in } \% \text { of bullding contents per day. } \\
\Delta \mathrm{P}= & \text { difference between reference tank pressurs and building } \\
& \text { pressure as measured with the } \mathrm{U} \text {-tube manometer, inches } \\
& \text { of } \mathrm{H}_{2} \mathrm{O} . \\
\Delta \mathrm{T}= & \text { reference tank temperatures minus bullding temperature, }{ }^{\circ} \mathrm{C} . \\
\Delta \Delta \mathrm{P}= & (\Delta \mathrm{P})_{t_{2}}-(\Delta \mathrm{P})_{\mathrm{t}_{1}} \\
\Delta \Delta \mathrm{T}= & (\Delta \mathrm{T})_{t_{2}}-(\Delta \mathrm{T})_{\mathrm{t}_{1}} \\
\mathrm{P}_{\mathrm{r}}= & \text { reference tank pressure, inches of } \mathrm{H}_{2} \mathrm{O} \text { (absolute). } \\
\mathrm{T}_{\mathrm{b}}= & \text { average building temperature, }{ }^{\circ} \mathrm{K} . \\
t_{2}-\mathrm{t}_{1}= & \text { duration of test period, hours. } \\
\mathrm{P}_{\mathrm{b}}= & \text { bullding pressure, measured from pressure taps attached } \\
& \text { to the containment bullding, inches of } \mathrm{H}_{2} \mathrm{O} \text { (absolute). }
\end{aligned}
$$

The values of $P_{b}, P_{r}$, and $T_{b}$ are measured at initial time, $t_{1}$.

The method used to convert the leak rate determined at $5 \mathrm{psig}$ to the equivalent leak rate at higher pressures is given in the Appendix. The leak rate at $5 \mathrm{psig}$ is multiplied by 3.8 to obtain the leak rate at 24 psig. Changes in the building air temperature do not introduce an error unless the $\Delta T$ changes. Seven thermocouples are provided, as shown in Figure 11, to determine reference tank and bullding temperatures. The maximum $\Delta \mathrm{T}$ variation was $0.7^{\circ} \mathrm{C}$. A $\Delta \mathrm{T}$ change of $\pm 0.7^{\circ} \mathrm{C}$ adds or subtracts $0.27 \%$ to the leak rate of $0.76 \%$ per day. The average $\Delta T$ between the reference tanks and bullding was $0.4^{\circ} \mathrm{C}$. The average change In $\Delta T$ from one hour to the next was $0.09^{\circ} \mathrm{C}$. This contributes only $\pm 0.04 \%$ to the leak rate. Thus, to keep potential errors from temperature differences to a minimum, the tops or bottoms of cycles are chosen as leak rate intervals. 
Good air distribution in the building kept the spread of temperatures from -52 feet to +48 feet between $1.2^{\circ} \mathrm{C}$ and $4.2^{\circ} \mathrm{C}$.

Figure 13 shows the effect of amblent temperatures. It can be seen that the highest temperatures occur in the late afternoon. The bullding then cools until about $7 \mathrm{AM}$ when the sun starts to heat 1 . When the bullding cools, the temperature leads the pressure. However, during heating, the pressure rise leads the temperature response. Although this behavior is probably due to some pecullarity of instrument response, it does cause difficulty with calculations.

Changes in vapor pressure of water inside the building affect the total pressure being measured. An increase in water vapor pressure causes an indicated increase in bullding pressure, or an apparent decrease in the leak rate. To provide information about water vapor pressure, four pairs of wet bulb-dry bulb thermocouples were installed in locations shown schematically in Figure ll. From the temperatures indicated in the control room, changes were calculated in humidity and water vapor pressure. Maximum differences occurred at sunrise and sunset as the bullding temperatures changed. The greatest change was an increase of about $\frac{1}{2}$ inch of $\mathrm{H}_{2} \mathrm{O}$. Average vapor pressure change was about 0.2 Inch of $\mathrm{H}_{2} \mathrm{O}$. This amount increases or decreases the leak rate by $0.10 \%$.

To calculate the leak rate between two times, it is necessary to use equation (I) and apply the water vapor change corrections. By this method the leak rates were calculated for the various time intervals in Table III. There 1s good agreement between the rates of lines 4, 6, 7 , and 8. Inaccurate temperature and water vapor pressure corrections probably cause the errors in the other lines except 1 and 2 . The high leak rates up to about 9:30 AM, May 4, are probably due to the absorption of the alr in the concrete. It is concluded that calculations made for a 24 or 48-hour period, or between night and morning, w111 be rellable.

A simpler method can also be used to calculate the leak rate. If the average of the temperature and water vapor pressure changes is zero, only the slope of the $\Delta \mathrm{P}$ curve is needed. If all the $\Delta \mathrm{P}$ data are valid, a statistical analysis gives the leak rate to any desired confldence. Temperature and water vapor pressure changes appear as scatter in the data. The slope of the $\Delta P$ curve was calculated by the method of least squares and the leak rate 1s:

$$
L=\frac{\Delta P}{\Delta t} \times \frac{24}{P_{b a}}
$$


where,

$$
\begin{aligned}
\Delta \mathrm{P} / \Delta \mathrm{t} & =\text { slope curve of } \Delta \mathrm{P} \text { versus time, inches of } \mathrm{H}_{2} \mathrm{O} \text { per hour. } \\
\mathrm{P}_{\mathrm{ba}} & =\text { average absolute building pressure, inches of } \mathrm{H}_{2} \mathrm{O} .
\end{aligned}
$$

From $11 \mathrm{PM}$, May 3, to $10 \mathrm{AM}$, May $6, \Delta \mathrm{P} / \Delta t=0.1660 \pm 0.0025$ (95\% confidence). From Figure 12, $\mathrm{P}_{\mathrm{ba}}=542.2$ inches of $\mathrm{H}_{2} \mathrm{O}$. A constant barometric pressure of 406.9 inches of $\mathrm{H}_{2} \mathrm{O}$ was assumed.

Then:

$$
\begin{aligned}
I & =(0.1660 \pm 0.0025) \times(24 \times 100) / 542.2 \\
& =4.43(0.1660 \pm 0.0025) \\
& =0.735+0.011 \% \text { per day }
\end{aligned}
$$

A pressure of 542.2 inches of $\mathrm{H}_{2} \mathrm{O}=4.83$ psig. By the method of the Appendix, the conversion factor to $5.0 \mathrm{psig}$ is 1.029 .

Then:

$$
\begin{aligned}
I & =(0.735 \pm 0.011) \times 1.029 \\
& =0.756 \pm 0.011 \% \text { per day }
\end{aligned}
$$

And at $24 \mathrm{psig}$

$$
\begin{aligned}
I & =(0.756 \pm 0.011) \times 3.792 \\
& =2.867 \pm 0.042 \% \text { per day }
\end{aligned}
$$




\section{TABLE III}

Leak Rates During 1963 Test

Dates and Times

1. 1 AM, May 4 to $7 \mathrm{AM}$, May 4
2. $1 \mathrm{AM}$, May 4 to $9: 30 \mathrm{AM}$, May 4
3. $10: 30 \mathrm{AM}$, May 4 to $3 \mathrm{PM}$, May 4
4. $6 \mathrm{PM}$, May 4 to $9 \mathrm{AM}$, May 5
5. $6 \mathrm{PM}$, May 4 to $6 \mathrm{PM}$, May 5
6. $8 \mathrm{AM}$, May 4 to $8 \mathrm{AM}$, May 6
7. $7 \mathrm{PM}$, May 4 to $6 \mathrm{PM}$, May 5
8. $5 \mathrm{PM}$, May 4 to $7 \mathrm{AM}$, May 5
9. $11 \mathrm{AM}$, May 5 to $11 \mathrm{PM}$, May 5
10. $7 \mathrm{PM}$, May 5 to $7 \mathrm{AM}$, May 6
11. $8 \mathrm{AM}$, May 4 to $4 \mathrm{PM}$, May 4

Time Interval, hours

$\begin{array}{ll}6 & 1.59 \\ 8.5 & 1.20 \\ 4.5 & 0.44 \\ 15 & 0.77 \\ 24 & 0.85 \\ 48 & 0.73 \\ 23 & 0.77 \\ 14 & 0.79 \\ 12 & 0.66 \\ 12 & 0.70 \\ 8 & 0.62\end{array}$

\section{Evaluation of Containment Building}

The experlence with the construction and testing of the buliding leads to the conclusion that the bullaing is structurally sound in all respects. Although the leak rate increased between tests durling the early history of the bullding, repalrs in electrical conduits and mechanical closures in the building accesses restored the leak rate to near 1\% per day at a pressure of $5 \mathrm{ps} 1 \mathrm{~g}$. During the interval of 15 months between the last two leak tests, the leak rate did not 1ncrease, indicating that a condition had been achieved in which routine maintenance was sufficient to maintain a steady state leak tightness.

The recommendations, discussed in Reference 4, for future bulldIngs of this type remain unmodifled by the test experience with this bullding. These recommendations, made by the original design and construction groups, are:

1. Pour the exterior concrete shell and the grade floor slab and prestress the shell prior to pouring the interior shielding walls and intermediate floor slabs. This sequence should ellminate cracks that resulted from pouring the shell against interior walls and slabs and then prestressing. 
2. Make the shell at least 24 inches thick. The greater thickness would permit personnel inside the forms to observe the pouring and provide more room for placing the concrete chutes and for vibrating the concrete.

3. Ellminate horizontal runs of conduit and piping in the grade level slab; condult and piping should emerge from the steel shell rather than from the concrete.

4. Provide greater spacing between the penetrations in the concrete shell to permit a better arrangement of restrictive reinforcement and to facilitate pouring.

5. Apply thermal setting plastic resin on all interior concrete surfaces.

\section{BIBLIOGRAPHY}

1. Denkins, R. F. and T. E. Northup. "Concrete Containment Structures." Nuclear Safety 6 , November 2, (Winter 1964-1965).

2. Arnett, L. M., et al. Final Hazards Evaluation of the Heavy Water Components Test Reactor (HWCTR). USAEC Report DP-600, E. I. du Pont de Nemours \& Co., Savannah RIver Laboratory, Alken, S. C. (1962).

3. Arnett, L. M., et al. Flnal Hazards Evaluation of the Heavy Water Components Test Reactor (HWCTR). USAEC Report DP-600A, E. I. du Pont de Nemours \& Co., Savannah RIver Laboratory, Alken, S. C. (1965).

4. Bellas, H. W. Composite Concrete - Steel Contalnment Vesse1 Engineering Cons1derations (HWCTR). USAEC Report DP-599, E. I. du Pont de Nemours \& Co., AED Process Section, Wilmington, Delaware (1961). 


\section{APPENDIX}

CONVERSION OF 5 psig LEAK RATE TO 24 psig LEAK RATE

The conversion factor used to convert the leak rate determined at $5 \mathrm{psig}$ to the equivalent leak rate at $24 \mathrm{psig}$ is derived as follows:

The equation below, for compresstble laminar flow, is assumed to hold for leakage through many small tortuous paths.

$$
W=K \frac{\bar{P} \Delta P}{T_{b}}
$$

where,

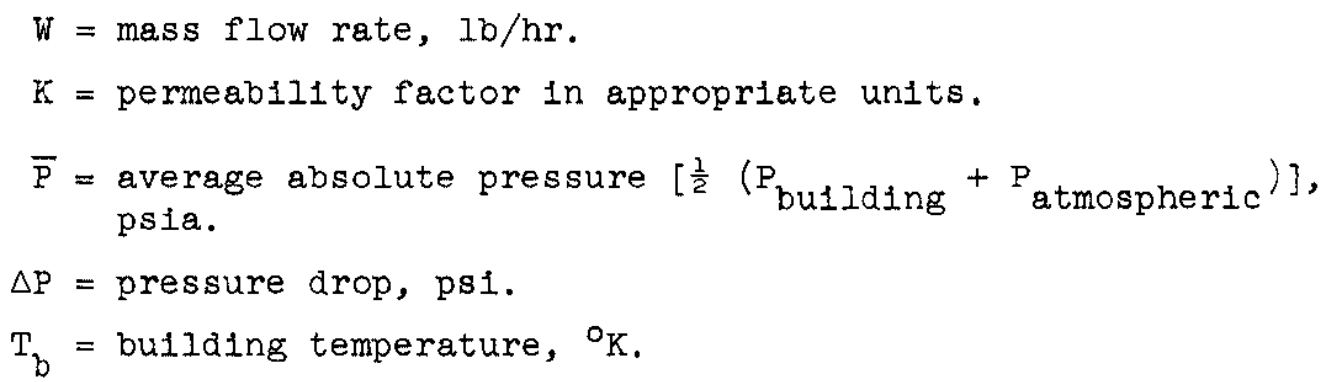

The inftial mass of air in pounds in the bullding is defined by:

$$
M_{0}=C \frac{{ }_{b_{0}}}{T_{b_{0}}}
$$

where,

$$
\begin{aligned}
\mathrm{P}_{\mathrm{b}_{\mathrm{O}}} & =\text { Initial building pressure, psia } \\
\mathrm{T}_{\mathrm{b}_{\mathrm{O}}} & =\text { initial building temperature, }{ }_{\mathrm{K}} \\
\mathrm{C} & =\begin{array}{l}
\text { a constant for the building and for air, in appropriate } \\
\text { units. }
\end{array}
\end{aligned}
$$

Subscript o refers to initial conditions.

The leakage rate, $L^{\prime}$, which is the mass of air leaked per day/ initial mass of air in building, can be expressed by combining equations (4) and (5) as follows:

$$
L^{\prime}=\frac{24 W}{M_{0}}=\left(\frac{K}{c}\right)\left(\frac{\overline{P_{\Delta}}}{P_{b_{0}}}\right)\left(\frac{T_{b_{0}}}{T_{b}}\right)(24)
$$


The ratio of $\mathrm{L}_{1}$ at $\mathrm{P}_{\mathrm{b}_{1}}$, to $\mathrm{L}_{2}^{\prime}$ at $\mathrm{Pb}_{2}$, can be expressed as follows:

$$
\frac{L_{1}^{\prime}}{L_{2}^{\prime} 2}=\left(\frac{\bar{P}_{1} \Delta P_{1}}{\bar{P}_{2} \Delta P_{2}}\right)\left(\frac{P_{b_{O_{2}}}}{P_{b_{O_{1}}}}\right)\left(\frac{\mathrm{T}_{b_{O_{1}}} T_{b_{2}}}{T_{b_{O_{2}}} T_{b_{1}}}\right)
$$

The temperature term, $\frac{\mathrm{T}_{\mathrm{b}_{1}} \mathrm{~T}_{\mathrm{b}_{2}}}{\mathrm{~T}_{\mathrm{O}_{\mathrm{O}_{2}}} \mathrm{~T}_{\mathrm{b}_{1}}}$, can be 1gnored because the building

temperature is malntained nearly constant by the air conditioning system.

The term $\bar{P}$, the average of the absolute pressure within the building and the absolute pressure outside the building, can be taken as a constant for any given test if the leakage is small.

The ratio of $\mathrm{L}_{1}$ at a test pressure of $24 \mathrm{psig}$ to $\mathrm{L}_{2}$ at a test pressure of 5 psig 1 s then:

$$
\frac{L_{1}^{\prime}}{L_{2}^{\prime}}=\left(\frac{26.7}{17.2}\right)\left(\frac{24}{5}\right)\left(\frac{19.7}{38.7}\right)=3.8
$$

In the case of turbulent flow, the mass flow equation is:

$$
W=\frac{K_{1}}{f} \sqrt{\frac{\bar{P}_{2} \Delta P_{2}}{\bar{P}_{2} \Delta P_{2}}}\left(\frac{P_{b_{O_{2}}}}{P_{b_{O_{1}}}}\right)\left(\frac{f_{2}}{f_{1}}\right)
$$

and the leakage ratio is:

$$
\frac{L^{\prime} 1}{L^{\prime}} \sqrt{\frac{\bar{P}_{1} \Delta P_{2}}{\bar{P}_{2} \Delta P_{2}}}\left(\frac{P_{b_{O_{2}}}}{P_{b_{O_{1}}}}\right)\left(\frac{f_{2}}{f_{1}}\right)
$$

where, $f$ is the friction factor.

The leakage ratios for turbulent flow are quite different, e.g., the $L_{1} / I_{2} \prime_{2}$ ratio for a test pressure ratio of $24 \mathrm{psig} / 5 \mathrm{psig}$ would be 1.39, as opposed to 3.8 for laminar flow (assuming the friction factor does not change appreciably).

The conversion factor of 3.8 was tested experimentally, on January 13, 1962, by increasing the test pressure from 5 to 12 psig. In this case the calculated $L_{1}^{\prime} / L_{2}^{\prime}$ ratio for the $12 / 5$ test pressure rat10 was 2.13 and the measured rat1o was 2.24. For this case, the $L_{1}{ }_{1} / L_{2}{ }_{2}$ ratio for turbulent flow 1 s 1.25 . It was concluded that the leakage occurred as laminar flow, and that the 3.8 conversion factor was correct. 
The rat10 of $\mathrm{L}_{1}^{\prime}$ at $\mathrm{P}_{\mathrm{b}_{1}}$, to $\mathrm{L}_{2}$ at $\mathrm{P}_{\mathrm{b}_{2}}$, can be expressed as follows:

$$
\frac{L_{1}^{\prime}}{L_{2}^{\prime}}=\left(\frac{\bar{P}_{1} \Delta P_{1}}{\bar{P}_{2} \Delta P_{2}}\right)\left(\frac{P_{b_{O_{2}}}}{P_{b_{O_{1}}}}\right)\left(\frac{T_{b_{O_{1}}} T_{b_{2}}}{T_{b_{O_{2}}} T_{b_{1}}}\right)
$$

The temperature term, $\frac{\mathrm{T}_{\mathrm{b}_{\mathrm{O}}} \mathrm{T}_{\mathrm{b}_{2}}}{\mathrm{~T}_{\mathrm{b}_{\mathrm{O}_{2}}} \mathrm{~T}_{\mathrm{b}_{1}}}$, can be ignored because the building

temperature is maintained nearly constant by the air conditioning system.

The term $\bar{P}$, the average of the absolute pressure within the bullding and the absolute pressure outside the bullding, can be taken as a constant for any given test if the leakage is small.

The ratio of $\mathrm{L}_{1}$ at a test pressure of $24 \mathrm{psig}$ to $\mathrm{L}_{2}$ at a test pressure of 5 psig is then:

$$
\frac{L^{\prime} 1}{L_{2}^{\prime}}=\left(\frac{26.7}{17.2}\right)\left(\frac{24}{5}\right)\left(\frac{19.7}{38.7}\right)=3.8
$$

In the case of turbulent flow, the mass flow equation is:

$$
W=\frac{K_{1}}{f} \sqrt{\frac{\bar{P}_{1} \Delta P_{1}}{\bar{P}_{2} \Delta P_{2}}}\left(\frac{P_{b_{O_{2}}}}{P_{b_{O_{1}}}}\right)\left(\frac{f_{2}}{f_{1}}\right)
$$

and the leakage ratio is:

$$
\frac{\mathrm{L}_{1}^{\prime}}{\mathrm{L}^{\prime}} \sqrt{\frac{\overline{\mathrm{P}}_{1} \Delta \mathrm{P}_{1}}{\overline{\mathrm{P}}_{2} \Delta \mathrm{P}_{2}}}\left(\frac{\mathrm{P}_{\mathrm{b}_{\mathrm{O}_{2}}}}{\mathrm{P}_{\mathrm{O}_{\mathrm{O}_{1}}}}\right)\left(\frac{\mathrm{f}_{2}}{\mathrm{f}_{1}}\right)
$$

where, $f$ is the friction factor.

The leakage ratios for turbulent flow are quite different, e.g., the $L_{1}{ }_{1} / L^{\prime}{ }_{2}$ ratio for a test pressure ratio of $24 \mathrm{psig} / 5 \mathrm{psig}$ would be 1.39 , as opposed to 3.8 for laminar flow (assuming the friction factor does not change appreciably).

The conversion factor of 3.8 was tested experimentally, on January 13, 1962, by 1ncreasing the test pressure from 5 to 12 psig. In this case the calculated $L_{1}^{\prime} / L^{\prime} 2$ ratio for the $12 / 5$ test pressure rat1o was 2.13 and the measured rat10 was 2.24. For this case, the $L^{\prime}{ }_{1} / L^{\prime}{ }_{2}$ rat10 for turbulent flow 1 s 1.25 . It was concluded that the leakage occurred as laminar flow, and that the 3.8 conversion factor was correct. 